\title{
指触覚による滑り知覚と自己受容感覚によるストローク再現の 利手/非利手への割当の比較
}

\author{
勝田 洸紀 ${ }^{* 1}$, 野村 由司彦 ${ }^{* 2}$, 加藤 典彦*3，稲垣 慎一 ${ }^{* 4}$
}

\section{Comparison between four assignments of slip-perception and stroke-reproduction task to dominant/nondominant hand}

\author{
Koki KATSUTA ${ }^{* 1}$, Yoshihiko NOMURA ${ }^{* 2}$, Norihiko KATO ${ }^{* 3}$ and Shinichi INAGAKI ${ }^{* 4}$ \\ ${ }^{* 1, * 2, * 3, * 4}$ Graduate School of Engineering, Mie University \\ 1577 Kurimamachiya-cho, Tsu-shi, Mie 514-8507, Japan
}

Received: 25 January 2019; Revised: 26 April 2019; Accepted: 15 July 2019

\begin{abstract}
The objective of this study is to compare four kinds of hand assignments of slip-perception and stroke-reproduction task to dominant/nondominant hand for right handed persons based on a device that can present slippages to users via their fingerpad skin. The device is called an "active-wheel-based finger-tactile interface (AWB-FTI)" in this paper. It is an interface that embodies an active wheel being rotatable in any directions, with any speeds, and with any time durations. The movements result in slippage stimuli on users' fingerpad skin. Then, users are supposed to recognize the slippages as line-segments in a mental image. The reproduction of the recognized line-segments as the hand strokes with proprioceptive sensations is effective for storing the recognition in users' memory. The performance of the device is measured by a pair of tasks composed of the slip-perception task and the stroke-reproduction task. Each of the pair of tasks should be assigned to either dominant hand or nondominant one. That is, four hand assignments are defined for the perception and the reproduction: the hand used for perception and that for the reproduction are "Dominant $\times$ ipsilateral," "Dominant $\times$ contralateral," "Nondominant $\times$ ipsilateral," and "Nondominant $\times$ contralateral." The reproduction errors of the four hand assignments were measured through a comparative psychophysical experiment with the slip-perception and stroke-reproduction task. As a result, we found the following characteristics: (1) as for the slippage-speeds and -angles, the nondominant hand was better than the dominant one from the viewpoints of both random and systematic errors in the perceptual hand, while either nondominant or dominant hand showed no significant difference in the reproductive hand, (2) as for the slippage time-durations, the "Dominant $\times$ contralateral" was worst in the four hand assignments from the viewpoint of random errors, and the "Nondominant $\times$ contralateral" was best from the viewpoint of systematic errors.
\end{abstract}

Keywords : Finger tactile interface, Slippage perception, Stroke reproduction, Speed, Length, Time duration, Direction, Dominant hand, Non-dominant hand

\section{1. 緒言}

人のハプティクス感覚 (皮膚の感覚だけでなく，手や腕などの身体の運動覚を統合した触運動覚や触力覚を含 む広義の触覚) の研究やハプティクス感覚を用いたインタフェースの研究は活発に行われている. 例えば, Provancher and Sylvester (2009) は指に外力を加えると同時に示指指腹部で触れている面を変位させて皮膚伸張刺 激を与えるデバイスを提案し摩擦係数の違いを仮想的に表現した. Koslover et al. (2012) は母指指腹部の接触面内 任意方向に皮膚伸張刺激を与える把持型の可搬デバイスを提案し，歩行誘導に応用した. Webster et al. (2005) は

No.19-00032 [DOI:10.1299/transisme.19-00032], J-STAGE Advance Publication date : 23 July, 2019

${ }^{* 1}$ 学生員, 三重大学大学院 工学研究科 (广514-8507 三重県津市栗真町屋町 1577)

*2 フェロー, 三重大学大学院 工学研究科

*3 正員, 三重大学大学院 工学研究科

${ }^{* 4}$ 三重大学大学院 工学研究科

E-mail of corresponding author: nomura@mach.mie-u.ac.jp 
小球を任意の方向に回転させて指先に滑り刺激を与える装置を提案した．特定の条件下での実験であるものの， 提示した 2 つのすべり刺激に関して，向きが異なるとの知覚は $25^{\circ}$ を越える条件で，速さが異なるとの知覚は 40\%を超える条件で，正答率が 60\%を越えるという結果が示されている. 同じく滑りを提示する装置として, Ho et al. (2015) は，4 本のベルトを直交 2 方向に編み込み，各ベルトの変位の正負と速さを組み合わせることで，任 意の変位と回転を示指指腹部に提示できる装置を提案した. 向きに関しては，2つのすべり刺激の向きが異なる と正しく知覚できる正答率は $35^{\circ}$ で $60 \%$ 程度であり, Webster et al. (2005) より少し劣化していた. 直交 2 方向へ の滑りを合成して提示しようとしたところに難しさがあったと考えられる. 彼らはまたベルトの表面に $4 \mathrm{~mm} ま$ たは $1 \mathrm{~mm}$ 間隔で, 直径 $0.5 \mathrm{~mm}$ の平頭凸点を形成し, 凸点が効果的であったことも報告しており, 本研究の装置 との共通点があり興味深い、いずれも機構は工夫されているが, 角度, 速度または長さしか提示できないなど性 能には改善の余地があった．これらに対して，触覚を介して速度や位置の変化を表すべクトルが提示できれば有 用であると考えられる. すなわち, 例えば, 歩行やカーナビでは, 位置ベクトルにより次の交差点など, 目標地 点の位置が提示できる. 速度べクトルは, それ自体で現在速度を提示でき, 速度変化パターンを変えることで通 報など何らかの情報を提示できる，速度べクトルの向きを変化させることで進路変更が案内できる．これらのよ うな用途において，ディスプレイは操作者の注意を奪ってしまう上に，日照下で視認できないが，触覚はそのよ うなことはなく, より安全なインタフェースが実現できる可能性がある. 視覚障碍者には, 歩行経路のメンタル マップ生成支援，歩行誘導，さらには線画や文字などの運筆学習支援などにも応用できる可能性もある.

筆者らは，触覚の中でも，図形や動きが提示できるということで，小円板(以下，「ホイール」とよぶ)の回転を 利用して指腹部の皮膚に滑りベクトルを提示できる装置としてアクティブホイール式指触覚インタフェース (Active-Wheel-Based Finger-Tactile Interface (AWB-FTI))を開発した．すなわち，Nomura and Iwabu (2014)では，同時 に 1 つの凸点が当たるように平面様の滑り面上に $12.5 \mathrm{~mm}$ 間隔で凸点列を形成することで滑り知覚の精度が向上 寸ることを示した，その知見を踏まえ，Nomura and Kato (2015)では，小型装置化を目指し，滑り面を平面から大

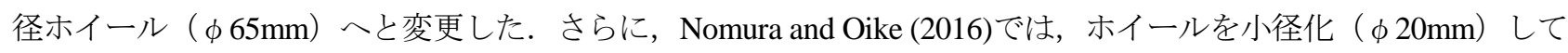
小型化を進めて可搬性を高めるとともに, 「凸点有り・厚い」ホイールが線分の知覚特性に優れていることを報告 した. そして, Nomura et al. (2018)では, すべりの提示を受けた後でマウスを走査する線画提示戦略 After-Recognition Go Strategy を提案し，3画までの多画線画に適用できることを確認した．本研究も「凸点有り・ 厚い」ホイールを使用している.

本論文の目的は，上記のような将来性を視野に入れ，AWB-FTI を前提として「ヒトの指触覚による凸点付き表 面の滑り速度知覚」／「腕の自己受容感覚による知覚量のストローク再現」の二つのタスクを片腕だけで行うの ではなく, 利手/非利手で使い分けることで，滑りベクトルの知覚・再現を高精度化するための基礎的知見を得 ることにある．触覚による滑り知覚やストローク再現の正確さは，知覚・再現を繰返し経験することにより習熟 し, 向上寸ることが期待される. したがって, 今後は本研究で取り上げた基礎的な特徵量である速度, 時間, お よび角度，それぞれにおける習熟特性を学習方法も工夫しながら調査する予定であり，本研究結果による利手／ 非利手の知覚・再現割当ては，その際の前提条件を定めるものと位置付けられる.

滑りに関するベクトルの特徵量は, 速さ, 時間, それらの組み合わせによる長さ, そして角度となる. 速さ, 時間, 角度に関して,「再現されたストローク」の「提示された滑り」からの誤差を系統誤差と偶然誤差に分けて, 利手／非利手の滑り知覚/ストローク再現への割当を比較検討する. ただし，実用を目指寸場合，上記のように 様々な用途に応じて提示す心゙き物理量は異なってくる. したがって, はじめに直接的な知覚要素である速さ, 時 間, 角度，それぞれで評価する，次に，運筆教示などの用途では，速さ，時間，角度をすべて利用すること，ま た軌跡にはすべてが反映されることを考慮して, 総合評価も行う.ここで, 提示した刺激を知覚するだけでなく, その知覚の再現まで併せて検討寸る理由を述べる，これは，認知している線画を他者に伝えるには，それを描画 することが必要であるが, さらには, 刺激により動作を知覚するだけでなく, 知覚した動作を実際に再現するこ とが動作学習に効果的であることに対応している. 寸なわち, Lüttgen and Heuer (2012)は, 提示した手先の軌道の 動作学習において, (1)視覚刺激のみにより知覚して学習した後, 学習結果を手先のストローク動作 (一画の運筆 に相当する運動) として再現する方法，および(2)視覚刺激を受けるだけでなくそれと同時に手先をストローク動 作させることで自己受容感覚も併せて用いて学習した後, 学習結果をストローク動作として再現する方法を比較 した．再現したストローク動作の速度軌道を提示した速度軌道に対寸る相関係数として評価した結果，(1)より(2) 
の方が有意に優れていることを示した．これは，知覚と再現を組み合わせて行うことにより短期学習性能が向上 することを示している．本研究では滑り刺激の知覚の後に自己受容感覚でストロークとして再現する特性を調べ ており，知覚と再現を組み合わせた効果的な短期学習過程に相当していると考えられる.

次に，知覚と再現を両腕で使い分けることについて従来研究を総括する. マッチング課題は，一方の腕 (肘関 節の研究が多い)で何らかの刺激を知覚し, それを一つの運動として認知し, 同側/反対側の腕で再現寸る課題で ある. この課題では, 知覚と再現の両腕間対称性 (知覚と再現の役割分担を左/右腕で入れ替えても同様な特性が 得られること) や別の刺激が重畳したときの影響が調べられた．例えば，Brockett et al. (1997)は，左または右の肘 関節の屈曲角度が特定の角度， $30,60,90^{\circ}$ となるように固定した後で，その角度に非固定腕の肘関節の屈曲角度 を合わせる実験を行った. Tsay et al. (2016) は, 基準とする片腕を屈曲または伸展方向に受動的に動かした後で, 基準腕の肘関節の屈曲角度と等しくなるように，反対側の腕を能動的に動か寸実験を行った．また，この実験で は利手, 非利手の影響を排除するため, ランダムに基準の腕と回答の腕を入れ替えている. Djupsjöbacka and Domkin (2005) は右肩関節を受動的または能動的に目標位置まで水平伸展運動させ, その後, 右肩関節を能動的 に目標位置に向けて水平伸展運動させる実験を行った。 また, 知覚に用いる手が，利手／非利手である場合の知 覚の性能を調べた研究もある. Han et al. (2013) は, 右利と左利の人を対象として, 利手, 非利手において, (母 指と示指でモノをつまむ)つまみ運動での自己受容感覚の性能を調べた. 右利と左利どちらも, 非利手で知覚する 方が性能が優れていた．また, Fraser and Harris (2017)は，外・内転方向に強制的に動かされた示指 MP 関節に， ス クリーンに映った白線を重㸚合わせる実験を行った. 示指 MP 関節の外・内転の角度誤差は非利手が優れていた. さらに, 知覚および再現に用いる手を利手, 非利手で使い分けることについての研究もある. Goble et al.(2005) は, 小児(8〜10 歳)の片腕をマニピュレータで動かし, 動かされた腕の肘関節の屈曲角度 (30) を腕の自己受容感覚 で知覚・再現する実験を行い, 非利手で角度を知覚し, 同側の腕 (非利手) で再現する場合が絶対誤差が小さく 優れていた. さらに, Goble and Brown $(2008,2010)$ は, 片腕をマニピュレータで動かし, 動かされた腕の肘関節の 屈曲角度 $\left(15 \sim 30^{\circ}\right)$ を同側/反対側の腕の自己受容感覚で再現する実験を行った. この研究では, 非利手で角度を 知覚し, 非利手 (同側) で再現する場合が絶対誤差が小さく優れていた. Goble and Brown (2009) は, 片腕をマニ ピュレータで動かし, 動かされた腕の肘関節の屈曲時の角速度を腕の自己受容感覚で知覚・再現する実験を行っ た. この研究では, 非利手で角速度を知覚し, 利手 (反対側) または非利手 (同側) で再現する場合が絶対誤差が 小さく優れていた. これらの研究結果から, AWB-FTIにおいても滑り刺激の知覚と再現を従来のように利手のみ を用いることが最善とはいえない，そこで，本研究では，「知覚に用いる手／再現に用いる手」の「利手／非利手」 の組合せに関する指針を得ることを目的とした，すなわち，右利き(男性)を前提として，知覚する手として「利 手／非利手」の 2 水準，および再現する手として知覚した手の「同側／反対側」の 2 水準による 4 つの組合せ水 準, すなわち, 「利手-同側 (利手で知覚して利手で再現)」,「利手-反対側 (利手で知覚して非利手で再現)」,「非利 手-同側」,「非利手-反対側」を比較した.

\section{2. 実験方法}

\section{$2 \cdot 1$ 実験装置}

AWB-FTI は, 水平軸周りで回転する薄板ホイールの回転, すなわちホイール自身の回転の角度と角速度, そし て回転軸の水平面内における旋回角度を制御できる. 図 1(a)(b)のように, 2 つのステッピングモータ, M $25 \mathrm{SP}-6 \mathrm{NK}$, およびM15SP-2N(ともにミツミ電機株式会社製)を用いて, それぞれ，ホイールの旋回角の制御，およびホイール 自身の回転速度と回転持続時間の制御を行っている. ホイールの旋回角は滑りの方向を定め, ホイール自身の回 転の速さと持続時間は，滑りの速さと長さを定める．ホイールは，緒言に述べた凸点有り・厚いに相当する径 20 $\mathrm{mm}$, 厚さ $6 \mathrm{~mm}$ とし, 表面には凸点を形成した. 凸点の形状は以下のように定めた。点字の凸点には JIS 規格(高 さ 0.3 0.5mm, 底部直径 1.3 1.7 mm の略半球形状)があり, これは, 小さいながらも知覚できること, そして皮 膚損耗を引き起こさないことなどに配慮していると考えられ，長年の実績がある．点字や点図の利用者は，凸点 の形成された面上で指腹部を滑動させながら点字を読むが，この動作は凸点を指腹部との間で相対的に滑らせる 本研究のデバイスの利用状況に共通していることから, 先の JIS 規格を援用し, 高さ $0.5 \mathrm{~mm}$, 底円直径 $1.7 \mathrm{~mm}$ と した．また，凸点間隔は，複数の凸点が指腹部に同時に接触しない $10.5 \mathrm{~mm}$ とした (図 2). 示指押当力を一定に 
保って知覚特性を安定させるため, 片端自由梁構造で示指爪上に錘を載荷する $0.5 \mathrm{~N}$ 定荷重載荷機構を取り付けた (図 1(c)). また，知覚した線分はタッチパネルディスプレイ (TPD, Dell S2240 21.5, 1920×1060) を用いて 1 画の 運筆運動 (以下，「ストローク」とよぶ) として再現した. このTPD は, AWB-FTI の右に隣接する形で AWB-FTI と一体となって，レール上で左右にスライドさせることができる.

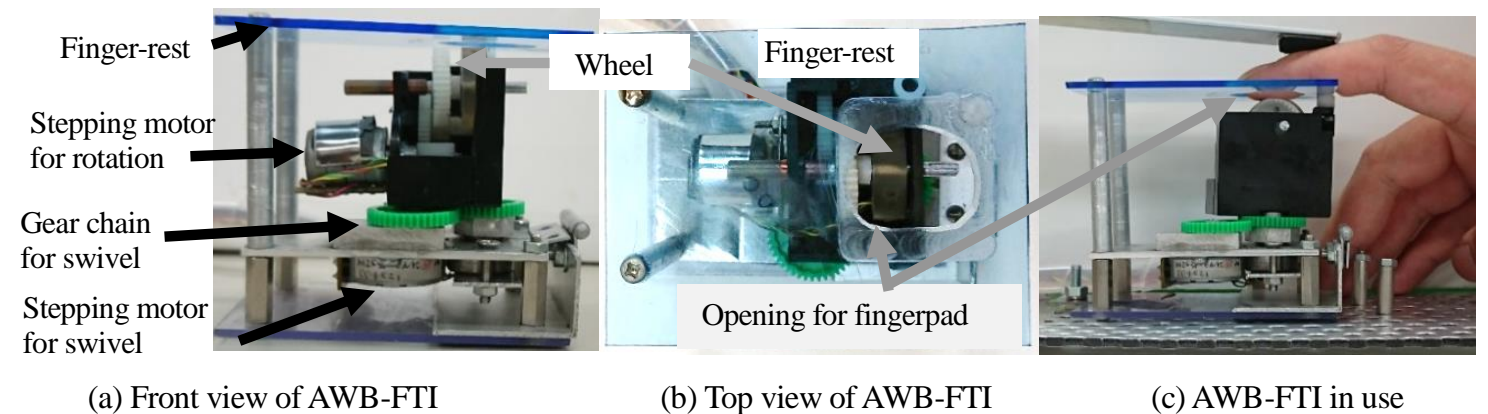

Fig. 1 AWB-FTI: a wheel is swiveled and rotated by two stepping motors.

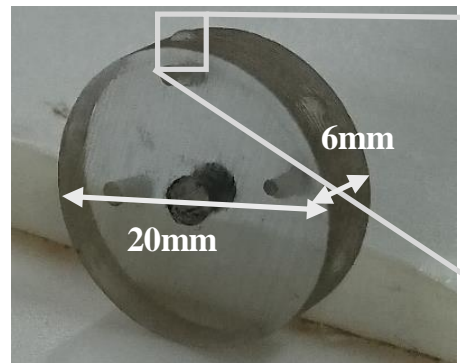

a) General view

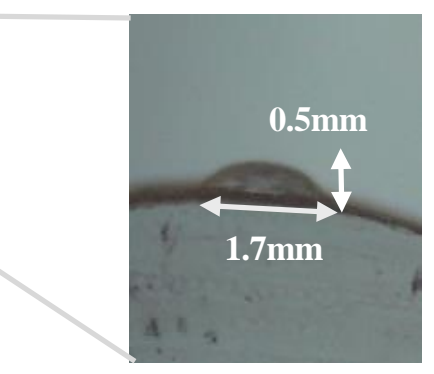

(b) Geometrical dimensions of a raised dot

Fig.2 Oblique perspective picture of the wheel.

\section{$2 \cdot 2$ 知覚 $\cdot$ 再現の利手/非利手割り当て}

AWB-FTI を用いて滑りの刺激を使用者に提示する．このとき，使用者は，後述の $2 \cdot 5$ 節での教示のように提 示された滑りを指腹部指触覚で知覚し，手の運動に関わる自己受容感覚を用いて再現する.このように AWB-FTI を用いて提示された滑り刺激を利手または非利手で知覚するとき精度が異なるのではないかと考えられる.また， 知覚した刺激をスタイラスペンによるストロークとして再現 (「ストローク再現」とよぶ) してもらうことで， 知覚も含めた再現の精度を評価した。この再現においても，知覚と同様に，利手または非利手の違いにより精度 が異なると考え，表 1 のように「知覚する手・再現する手」の寸べての組み合わせについて調査した. すなわち，

「利手/非利手の知覚・再現への割当 (以下，「知覚・再現割当」あるいは割当とよぶ)」は「利手-同側 (利手で知 覚, 利手で再現)」,「利手-反対側 (利手で知覚, 非利手で再現)」, 「非利手-同側 (非利手で知覚, 非利手で再現)」,

「非利手-反対側 (非利手で知覚, 利手で再現)」の 4 水準とした。

Table 1 Slippage-perception×stroke-reproduction assignment: right handers are assumed in the bracket.

\begin{tabular}{c|c|c|c|c}
\hline Task Assignment & $\begin{array}{c}\text { Dominant } \times \\
\text { ipsilateral }\end{array}$ & $\begin{array}{c}\text { Dominant } \times \\
\text { contralateral }\end{array}$ & $\begin{array}{c}\text { Nondominant } \times \\
\text { ipsilateral }\end{array}$ & $\begin{array}{c}\text { Nondominant } \times \\
\text { contralateral }\end{array}$ \\
\hline $\begin{array}{c}\text { Slippage-perception } \\
\text { hand }\end{array}$ & $\begin{array}{c}\text { Dominant } \\
\text { (right hand) }\end{array}$ & $\begin{array}{c}\text { Dominant } \\
\text { (right hand) }\end{array}$ & $\begin{array}{c}\text { Non-dominant } \\
\text { (left hand) }\end{array}$ & $\begin{array}{c}\text { Non-dominant } \\
\text { (left hand) }\end{array}$ \\
\hline $\begin{array}{c}\text { Stroke-reproduction } \\
\text { hand }\end{array}$ & $\begin{array}{c}\text { Ipsilateral } \\
\text { (right hand) }\end{array}$ & $\begin{array}{c}\text { Contralateral } \\
\text { (left hand) }\end{array}$ & $\begin{array}{c}\text { Contralateral } \\
\text { (left hand) }\end{array}$ & $\begin{array}{c}\text { Ipsilateral } \\
\text { (right hand) }\end{array}$ \\
\hline
\end{tabular}

\section{$2 \cdot 3$ 実験条件}

2 ・2 節で述べた割当も併せ, 実験条件を表 2 に示寸. 被験者は全員が右利の男性 8 名 (22 24 歳, 平均 23.0 歳) である. 提示した滑りは，速さ因子で 10, 17, 29, $50 \mathrm{~mm} / \mathrm{s}$ の 4 水準，時間因子で $1.0,1.7,2.9,5.0 \mathrm{~s}$ の 4 水準とし， 
これら 2 因子 4 水準総当たりの組合せ 16 種類を疑似ランダム系列で提示した．角度因子は，他と同じように 4 水準に絞り込むと, 被験者が予測できてしまい知覚精度を測れなくなってしまう，そこで， $0^{\circ}$ (右方向)から反時 計方向に $350^{\circ}$ まで $10^{\circ}$ 刻みの中から表 2 に示寸ように 16 水準をランダムに抜き取り，これを上記の組合せ 16 種類に割り当てた．ただし，角度の違いが 4 つの割当間で異なった影響をもたらさないよう，この速さ×時間 $\times$ 角度の組合せ水準はすべての割当，すべての被験者において同一とした。

また，被験者は 4 種の割当のすべてについて実験を行ったが，順序効果が均等になるように 8 名の間で疑似ラ ンダムに 4 種を提示した. 結局, 4 種の割当のそれぞれに 4 種の速さ, 4 種の時間, 計 $4 \times 4 \times 4=64$ ラン (提示・ 再現一組をランと呼ぶ) の 1 セットを 2 セット繰り返し, 8 名で計 $4 \times 4 \times 4 \times 8 \times 2=1024$ ランの実験を行った. 実験時間は 4 種の割当のそれぞれについて，十分に慣れてもらうための事前練習(10 ラン，5 分)も含め， 1 名約 80 分であった. 実験後, 知覚に対する疲労について，4段階の評定值によるアンケートをとった．その標語は以 下の通りである。「3, 疲労しなかった」「2, 疲労したが, 知覚・再現には影響はなかった」「1, 疲労し, 知覚・ 再現にいくらか影響した」「0, 疲労のため, 知覚・再現が困難になった」その結果, 7 名が評定 3,1 名が評定 2 であり, 疲労による知覚・再現への影響は認められなかったといえる.

Table 2 Experimental conditions.

\begin{tabular}{|c|c|c|c|c|}
\hline Factor & \multicolumn{4}{|c|}{ Level } \\
\hline $\begin{array}{l}\text { Slippage-perception } \times \\
\text { stroke-reproduction assignment }\end{array}$ & $\begin{array}{c}\text { Dominant } \times \\
\text { ipsilateral }\end{array}$ & $\begin{array}{l}\text { Dominant } \times \\
\text { contralateral }\end{array}$ & $\begin{array}{l}\text { Nondominant } \times \\
\text { ipsilateral }\end{array}$ & $\begin{array}{c}\text { Nondominant } \times \\
\text { contralateral }\end{array}$ \\
\hline The number of subjects & \multicolumn{4}{|c|}{8} \\
\hline Speed & \multicolumn{4}{|c|}{$10,17,29,50 \mathrm{~mm} / \mathrm{s}$} \\
\hline Time duration & \multirow{2}{*}{\multicolumn{4}{|c|}{$\begin{array}{c}1.0,1.7,2.9,5.0 \mathrm{~s} \\
0,140,150,170,190,230,240\end{array}$}} \\
\hline Direction & & & & \\
\hline
\end{tabular}

\section{$2 \cdot 4$ 被験者の姿勢}

AWB-FTI と TPD は水平面に対して $30^{\circ}$ 傾斜させるとともに，顎台を水平面に対して $60^{\circ}$ 傾斜させ，被験者の 視軸が TPD に垂直になるようにした．被験者は背筋を伸ばして椅子に座り，顎台に顎を乗せ，実験時，上腕は 鉛直に，前腕は肩関節を内旋させて前額平行面に対して $45^{\circ}$ に向けさせた. 手関節は肩関節の内旋と相殺するよ うに $45^{\circ}$ 尺屈させ，示指の遠・近位方向を AWB-FTI の長手方向に一致させた. 被験者にはヘッドフォンを装着 させ，実験合図を伝えるとともに，モータ音による滑り知覚への影響防止のためホワイトノイズを聴かせた。

\section{$2 \cdot 5$ 実験手順}

\section{[被験者に対する教示]}

実験の前，手順の説明に先立って以下を被験者に教示した.

(a) 滑りの知覚について : 触れているホイールは鉛直軸の回りで任意の方向に旋回し, その後, ホイールの水平 軸の回りで一定の角速度で任意の角度だけ回転します.このとき, 実際には円筒面が等速回転していますが, 平面が台に平行に一定の速度で動いていると感じてください.

(b) 滑りの刺激について : AWB-FTI から与えられる滑りの刺激は, 速さ (方向付き), 時間, 線分の長さと向き です，その内，滑りの速さ (方向付き)と時間に注意を向け，それらを組み合わせることで，速さを伴う 1 画 の運筆運動と認識, 記憶してください.

このように，本実験は，対象の FTI を前提として，す心゙り刺激に対して「触れている面が等速平面運動してお り, それが 1 画の運筆運動を表すと解釈してください」との実験者による教示の下ですべり知覚・ストローク再 現特性を調べるものである. その意味で, 特段の解釈を求めない条件での知覚を調査するものではない. 以下では，各ランの滑り提示・ストローク再現の手順を，教示に基づく被験者の応答も含め，説明する.

\section{[手順 1] 準備}

(a) 実験者は，ホイールが被験者の正中矢状面内に位置するように TPD が連結されている AWB-FTI を左方にス ライドさせる. 
(b) ヘッドフォンから「Set your finger」の合図が聞こえたら, 被験者は示指の指腹部がホイール外周面の上部に 当たるように手首を屈曲させ, 示指の爪の上面に載荷機構を乗せる. 次に示指を持ち上げて (伸展させて) ホ イールから離し, 閉眼寸る. その後, 実験者は提示する滑りの方向にホイールの方向を変化させる.

\section{[手順 2] 線分の知覚・記憶}

(c) ヘッドフォンから「Put your finger」の合図が聞こえたら, 被験者は示指を脱力・屈曲させ, AWB-FTI 上面の 円形開口部を通して指腹部をホイール外周面上に置く。この時，被験者は指先でホイールに触れてから「回 転」するまでの間，ホイールに触れた時の曲率の刺激によりホイールの方向を知覚し，これを次に提示され る滑りの方向と認知し，記憶する. (注意 : この時点では $180^{\circ}$ 正反対の滑りの向きのいずれかはわからない)

(d) ホイールが回転を始めたら, 被験者は, 直前に記憶した始点における方向も参考にして, 指先に伝わる滑り の向きを知覚し，さらにこの向きを線分の向きと認知する．その後，回転の速さが一定であるとして滑りの 速さを認知する．同時に経過した時間も認知する．このように認知した滑りの向き，速さ，時間の組により ストロークとして記憶する (図 3(a)).

（e） 実験者が定荷重載荷機構のレバーを示指から離す. 被験者は示指を持ち上げ，その状態で待機する.この間, 記憶したストロークを想起する. 実験者が被験者の手の下方まで TPD を左方にスライドさせる .

\section{[手順 3] 知覚・記憶した線分の再現 :}

(f) 提示終了の 2 秒後, 「Start」の合図がある.この時被験者は閉眼したまま, 記憶したストロークの始点に相 当する TPD 上の点にスタイラスペンを降す (図 3(b)). なお，スタイラスペンは，「反対側」条件ではそのラ ンの当初から持ち続け，「同側」条件では滑りを知覚した手で持ち直す.

（g）被験者は，記憶した線分の向きに，記憶した時間に到達するまで記憶したストロークの速さと向きにスタイ ラスペンを動かすことで再現する(図 3(c)).

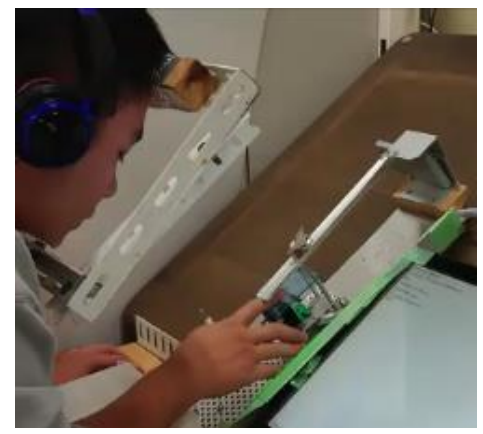

(a) Accepting wheel rotation, a subject creates a mental image of a presented slippage.

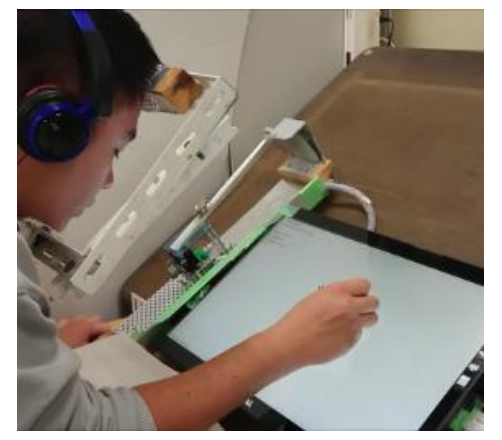

(b) Subject puts down a stylus pen on a TPD screen.

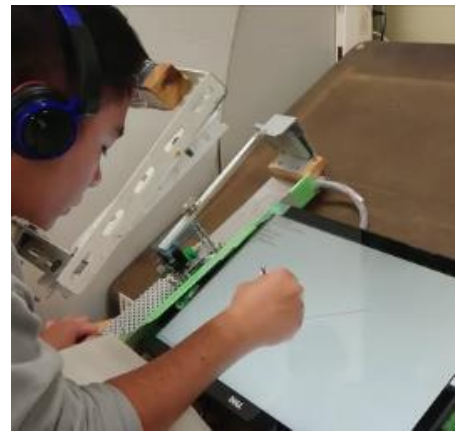

(c) Subject traces the mental image on the TPD by the stylus pen.

Fig.3 Sequence of procedure for the line-segment presentation/perception experiment.

\section{3. 実験結果}

被験者に注意を向けさせた速さ・時間・角度の知覚についての実験結果を述べ，考察する．被験者のストロー ク再現に関して計測されるデータは，時刻対応での 2 次元位置，すなわち「位置軌道」である．ここで，提示軌 道と再現軌道，それぞれにおいて，始点から終点に至る2次元の「軌跡」の始点と終点を結んだ線分の長さをも って, 提示長さ $L$, 再現長さ $l_{\text {reproduction }}$ と定義した. また, 動作の開始から終了までの経過時間をもって, 提示時 間 $T$, 再現時間 $\tau_{\text {reproduction }}$ と定義した. 次に, これらを用い, 提示速度 $V=L T$, 再現速度 $v_{\text {reproduction }}=l_{\text {reproduction }} / \tau_{\text {reproduction }}$ と求めた. また, その線分の向きにより, 提示角度 $\Theta$, 再現角度 $\theta_{\text {reproduction }}$ を求めた. 以下において, 速度の残差 は, 速度再現值 $v_{\text {reproduction }}$ の線形回帰モデルによる速度推定值 $v_{\text {model }}$ からの差, $v_{\text {reproduction }}$ - $v_{\text {model }}$ であり, 時間の残差 
は時間再現值 $\tau_{\text {reproduction }}$ の線形回帰モデルによる時間推定值 $\tau_{\text {model }}$ からの差， $\tau_{\text {reproduction }}-\tau_{\text {model }}$ である.また，角度の 誤差は再現角度 $\theta_{\text {reproduction }}$ の提示角度 $\Theta$ からの差, $\theta_{\text {reproduction }}$ - $\Theta$ を表す.

本実験ではさまざまな速さと時間の組合せ条件でデータを取ったが，その中で二つの典型的な条件，すなわち (a) 最も遅くて長時間の条件，および (b) 最も速くて短時間の条件における軌跡と速度時系列を図 4 に示す. な お, 軌跡において, ストローク再現の開始位置は特に指定していないので, 破線矢印で示される参照軌跡も含め, 各軌跡の並進移動は比較の対象外である. また, 凡例に示す $\mathrm{a}$ から $\mathrm{h}$ は各被験者を表す. 各被験者のストローク の向きは参照軌跡の向きに近かったので，特に記載していない。これらの図から，まず，参照軌跡に関しては， (a), (b)いずれの条件でも概ね提示と同様に再現されていることが見て取れる. 他方，速さは，低速条件では，提 示よりも大きめの速さまで急速に増加して後, 提示よりも短かい等速区間を経て, 急速に減少する傾向が見て取 れる．他方の高速条件では，提示された速さに追い付けないあまり，余分に時間をかけて加・減速している傾向 が見て取れる. 結果的に両条件の提示速さの比 $5(=50 / 10)$ に対し, 再現速さの比は 2 程度に小さくなっている.
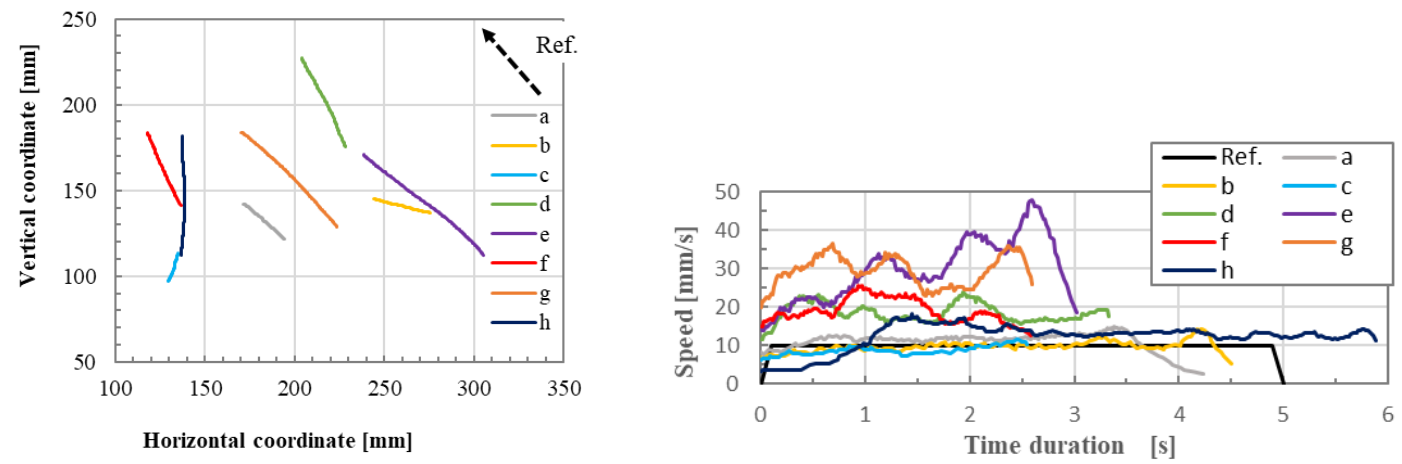

(a) Loci and speed-trajectories under the slowest and long time-duration condition.
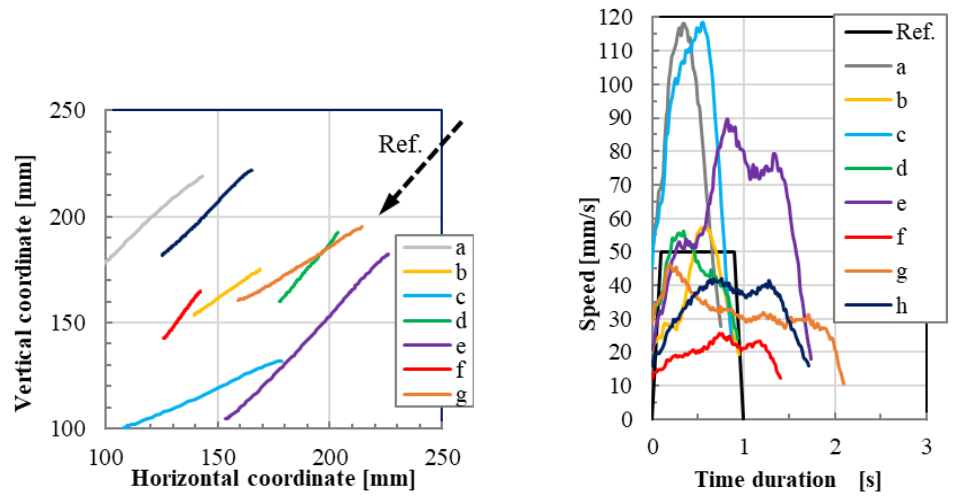

(b) Loci and speed-trajectories under the fastest and short time-duration condition.

Fig. 4 Some experimental results of reproduced strokes under the two extreme conditions.

実際には，滑りの速さ，時間，角度，それぞれの再現量（目的変数とよぶ）に対し，提示量（説明変数とよぶ） のうち, 同種のものだけでなく, 同種でないものも寄与することがある. 装置を使用する上では, 各目的変数に おいて, 同種の説明変数の寄与が他に比べ大きいと, 目的変数に対する説明変数の関係がわかり易く, 望ましい. このような観点で，本論文では，再現量と同種の提示量ができる限り近い值となるような「利手/非利手の知覚・ 再現への割当」を見出そうとしている，そこで，以下では，速さ，時間，角度，それぞれの目的変数において， 説明変数の寄与を比較するため, 重回帰分析を行った. ただし, 変数の変域の大きさを揃えるため各変数は標本 平均 0 , 標本分散 1 に標準化した. なお, 被験者, 割当, 回数は, 提示量ではないことからここでは比較は行わ なかった．表 3 は目的変数のそれぞれに対して，すべての説明変数を用いた Full model の場合を上段に，目的変 数と同じ説明変数のみを用いた Simplest model の場合を下段に示す. 各列には各説明変数の標準偏回帰係数 (Standard partial regression coefficient, SPRC), $t$-值, 有意確率 $p$-值，および各 model の自由度調整済重相関係数 (Multiple correlation coefficient adjusted for DOF, AMCC) が示されている. 下段から，目的変数と同種の説明変数の 
みを用いた Simplest model の AMCC は Full model と同程度であることがわかる，それを裏付けるように，上段の 標準偏回帰係数 SPRC を見てみると，例えば，目的変数「速さ」においては，それと同種の説明変数「速さ」の SPRC は 0.49 である一方で，それと異なる説明変数である「時間」のSPRC は-0.18，および「角度」のSPRC は -0.04 であった. 目的変数「速さ」に対する重回帰式を算出するなら, 各 $\operatorname{SPRC} の p$ 值に基づいて, 説明変数とし ては「速さ」と「時間」が選択されることになる，さて，SPRCの絶対值において，「速さ」の「時間」に対する 差 0.31 (=0.49-0.18), および「速さ」の「角度」に対する差 $0.45(=0.49-0.04)$ は, $t$ 值がそれぞれ 8.08 および 11.53 となった，その $p$ 值はいずれも 0.00 であり，「速さ」の寄与が有意に大きいことが確認された. この目的変数と 同種の説明変数の寄与が有意に大きい傾向は,「時間」,「角度」の目的変数ではさらに顕著に認められた. 以上の 確認の後, 次節以降では 4 つの割当間で, 再現量と同種の提示量との関係としての勾配を求め, 知覚・再現特性 を比較する．なお，割当因子全体の因子効果を求めるものではなく，単に有意な割当を求めるものであることか ら，分散分析は行わず，各割当間の勾配の有意差を検出する多重比較を行った.

Table 3 Results of standard multiple regression analyses for each of the criterion variates against the explanatory variates.

\begin{tabular}{|c|c|c|c|c|c|c|c|c|c|c|c|c|c|c|c|c|c|}
\hline & & \multirow[t]{2}{*}{ Criterion variate } & \multicolumn{5}{|c|}{ Speed } & \multicolumn{5}{|c|}{ Time duration } & \multicolumn{5}{|c|}{ Direction } \\
\hline & & & PRC & SPRC & $t$-value & $p$-value & AMCC & PRC & SPRC & $t$-value & $p$-value & AMCC & PRC & SPRC & $t$-value & $p$-value & AMCC \\
\hline \multirow{8}{*}{$\begin{array}{c}\text { Explanatory } \\
\text { variate }\end{array}$} & \multirow{4}{*}{ Full model } & Speed & 0.51 & 0.49 & 17.66 & 0.00 & \multirow{4}{*}{0.54} & 0.01 & 0.15 & 8.22 & 0.00 & \multirow{4}{*}{0.82} & -0.12 & -0.02 & -2.53 & 0.01 & \multirow{4}{*}{0.98} \\
\hline & & Time duration & -1.86 & -0.18 & -6.77 & 0.00 & & 0.71 & 0.81 & 45.14 & 0.00 & & 0.18 & 0.00 & 0.43 & 0.67 & \\
\hline & & Direction & -0.01 & -0.04 & -1.28 & 0.20 & & 0.00 & 0.01 & 0.72 & 0.47 & & 0.96 & 0.97 & 136.43 & 0.00 & \\
\hline & & Constant & 20.45 & 0.00 & 14.22 & 0.00 & & 0.16 & 0.00 & 1.95 & 0.05 & & 9.92 & 0.00 & 4.37 & 0.00 & \\
\hline & \multirow{4}{*}{ Simplest model } & Speed & 0.52 & 0.50 & 18.64 & 0.00 & \multirow{4}{*}{0.50} & & & & & \multirow{4}{*}{0.81} & & & & & \multirow{4}{*}{0.98} \\
\hline & & Time duration & & & & & & 0.71 & 0.81 & 44.20 & 0.00 & & & & & & \\
\hline & & Direction & & & & & & & & & & & 0.97 & 0.98 & 145.82 & 0.00 & \\
\hline & & Constant & 14.20 & 0.00 & 16.66 & 0.00 & & 0.55 & 0.00 & 11.12 & 0.00 & & 6.31 & 0.00 & 4.74 & 0.00 & \\
\hline
\end{tabular}

\section{$3 \cdot 1$ 速さ知覚 · 時間知覚}

全被験者をまとめた全体の傾向を見てみよう．4つの知覚・再現割当，すなわち利手-同側，利手-反対側，非利 手-同側，非利手-反対側のそれぞれに対して，滑りの提示速さ $V$ と再現速さ $v$ の関係を図 5 左図に，滑りの提示 時間 $T$ と再現時間 $\tau$ の関係を図 5 右図に示寸．図中，記号は各割当における $v$ およ゙ $\tau$ の平均を，エラーバーは 標準誤差を表す(各記号のデータ数 $n=256$ ). また，4つの割当における提示と再現の関係に関する線形回帰直線 を，それぞれ，青実線，緑破線，黄色破線，橙鎖線により示す．黒色実線は Ideal slope，すなわち提示と再現が 一致する理想の関係，すなわち勾配 1 , 切片 0 を表す. 線形回帰直線はデータ全体をモデル化したものであるこ とから，回帰直線の提示量に対する誤差は系統誤差といえる。この図から，速さ，時間のいずれにおいても，4 つの割当のすべてで提示が小さい時には大き目，大きい時には小さめに再現する傾向が見られる．ここで，切片 はすべての提示に対する再現をまとめた偏りを表す.勾配は, 提示の変化量に対する再現の変化量の割合を表す. 提示量に対して，0 との違いという意味で大きさを評価する場合には切片も重要であるが，滑りに関する提示の 違い，すなわち滑りの変化の幅の正確な再現を評価するならば，勾配が 1 に近いことが望ましい，その意味で系 統誤差が小さいということになる.このように考え, 4 つの割当に関する $6 つ$ 割当対の間の勾配の差について, 各被験者において 4 つの知覚・再現割当の差を取った「対応のある $t$ 検定 (paired $t$-test, 以下では単に「 $t$ 検定」 と記す)」により検定した．また，偶然誤差の評価值として回帰直線からの残差を用いた４割当に関する6つの 割当対の間の残差の分散比の大きさの有意性の有無を「両側 $F$ 検定」により検定した. なお， $F$ 検定， $t$ 検定， いずれも, Bonferroni による多重比較の補正を行った。ここで, 検定がサンプルサイズによって変化するのに対 して, サンプルサイズによって変化しない指標として「効果量. $d$ (effect size, Cohen, 1988)」がある. 分散比は, 基本的にはサンプルサイズの影響を受けないので効果量(effect size)としての意味もあり, 本研究では 1.5 またはそ の逆数 $0.7(=1 / 1.5$. (Buchner et al., 2019) を基準值とした. 差の効果量 $d$ は Cohen (1988)による効果量小 0.2 を基 準値とした．また，母分散の比や母平均の差が，有意水準 $5 \%$ に相当する境界值より大きい確率は「検定力 1- $\beta$ (power) 」と呼ばれるが, これについては 0.8 を基準值とした (Cohen, 1992) . 以下の検定に際してはこれら効果 量と検定力についても補足的にコメントする. 

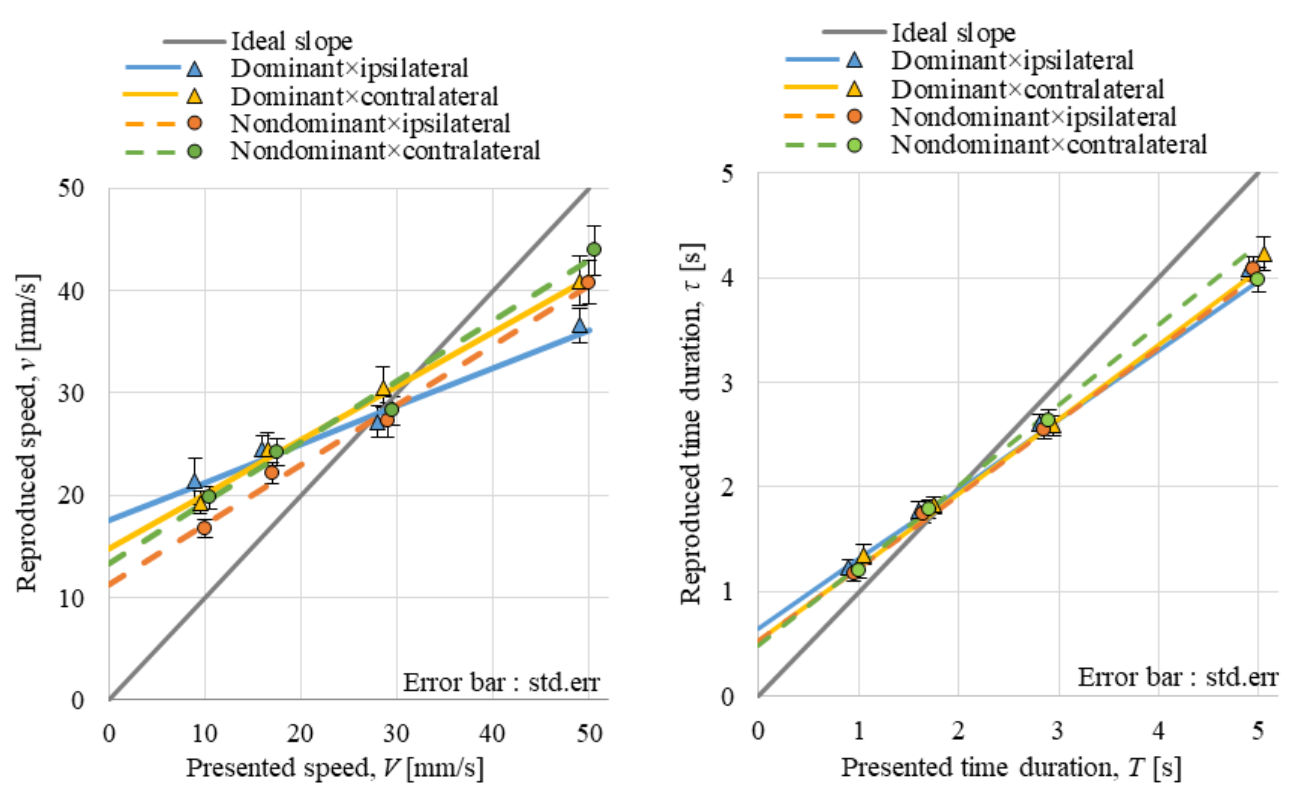

Fig.5 Characteristics of reproduced speed and time-duration for the four kinds of perception $\times$ reproduction assignments.

(1) 図 5(a)に基づいて，再現されたストロークの速さについて 4 つの割当を比較する. まず，速さの残差の分散比 の $F$ 検定結果を図 6(a)に示寸. 図のように分散は, 利手-同側が $281.5(\mathrm{~mm} / \mathrm{s})^{2}$, 利手-反対側が $267.7(\mathrm{~mm} / \mathrm{s})^{2}$, 非利手-同側が $185.9(\mathrm{~mm} / \mathrm{s})^{2}$, 非利手-反対側が $210.3(\mathrm{~mm} / \mathrm{s})^{2}$ であった. 総じて, 分散は, 知覚において非利手 が利手より優れていたが，再現においては同側と反対側の間に特定の傾向は見られなかった．分散比の $F$ 検 定では, 非利手-同側の分散が利手-同側および利手-反対側の分散に対して有意に大きく, 劣っていると認めら れた．そのときの効果量としての分散比は 1.4 または 1.5 となっており，基準值を概ね満たしたが，検定力は 基準值に比してやや小さい值となった.

次に，知覚・再現の変化量の比である「回帰直線の勾配」に対し，4つの割当における速さの勾配を，各被 験者毎の対応を考慮した, 対応あり $t$ 検定の結果を図 6(b)に示す. 勾配の推定値は, 利手-同側が 0.37 , 利手反対側が 0.53 , 非利手-同側が 0.59 , 非利手-反対側が 0.59 であった. 総じて, 勾配は, 知覚において非利手が 利手より 1 に近く優れており（検定は，1 に近いことに関する検定ではなく, 二つの割当の勾配の差に対して 行っていることに注意されたい，以下も同様），再現において反対側が同側に比して同等以上であり，「非利 手知覚-反対側再現」優位傾向が見られる. 勾配差の $t$ 検定結果において, 利手-同側が他の三つの割当に対し て有意に 1 から遠く劣っていた. そのときの効果量と検定力は上記の基準值を上回った.

(2) 図 5(b)に基づいて, 再現されたストロークの時間の残差について 4 つの割当を比較する. まず, 時間の残差 の分散比の $F$ 検定結果を図 7(a)に示寸. 図のように分散は, 利手-同側が $0.68 \mathrm{~s}^{2}$, 利手-反対側が $1.00 \mathrm{~s}^{2}$, 非利手同側が $0.71 \mathrm{~s}^{2}$, 非利手-反対側が $0.82 \mathrm{~s}^{2}$ であった. 利手-反対側が他の三つの割当に比して劣っている傾向が見 られる. 総じて, 分散は, 知覚において非利手が利手より, 再現において同側が反対側より優れる「非利手知 覚-同側再現」優位傾向が見られる．分散比の $F$ 検定結果において，利手-反対側が利手-同側および非利手-同 側に対して有意に大きく, 劣っていると認められ, そのときの効果量としての分散比はいずれも 1.4 となって おり，基準值を概ね満たし，検定力は基準值に比してやや小さい值となった。

次に, 時間に関する回帰直線の勾配に対し, 対応あり $t$ 検定を適用した結果を図 7(b)に示す. 勾配は, 利手 -同側が 0.66, 利手-反対側が 0.71, 非利手-同側が 0.70, 非利手-反対側が 0.77 であった. 総じて, 勾配は, 知 覚において非利手が利手より, 再現において反対側が同側より 1 に近く優れる「非利手知覚-反対側再現」優 位傾向が見られる. 勾配差の $t$ 検定結果において, 非利手-反対側が他の三つの割当に対して有意に 1 に近く 優れていると認められたが，その時の効果量 $d$ および検定力 1 - $\beta$ は基準值を若干下回っていた. 


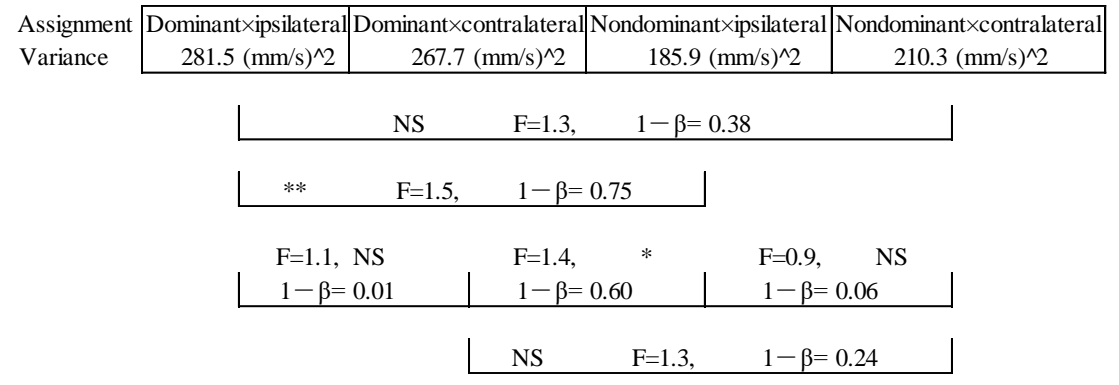

Bonferroni corrected prob: NS: $p>=0.1,+: p<0.1, *: p<0.05, * *: p<0.01, * * *: p<0.001$

(a) F-test on two variance inequality of speed.

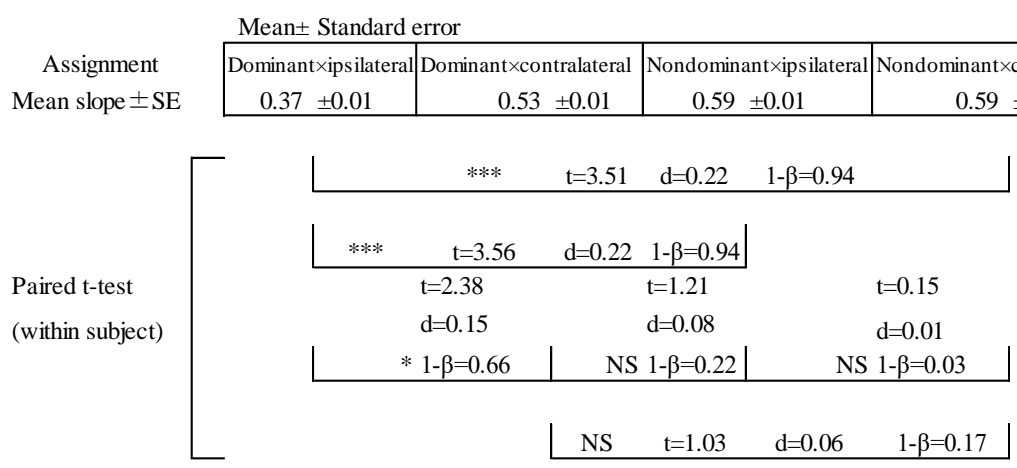

Bonferroni corrected prob: NS: $p>=0.1,+: p<0.1, *: p<0.05, * *: p<0.01, * * *: p<0.001$

$d=\Delta_{\text {slppe }} / s_{\triangle \text { slppe }} \triangle_{\text {slope }}$ :Mean estimated slope difference $s_{\triangle \text { slppe }}:$ Root mean square residuals per datum

(b) Paired t-test for the population mean slope-differences.

Fig.6 Test results on speed perception-and-reproduction.

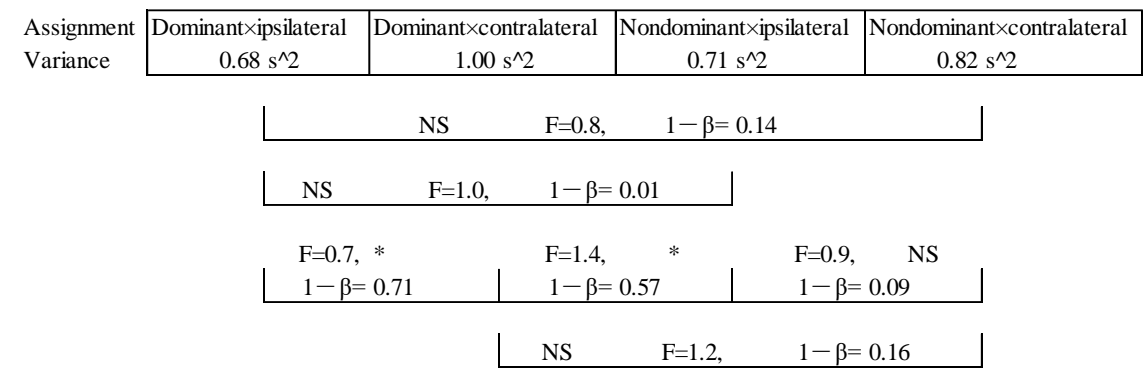

Bonferroni corrected prob: NS: $p>=0.1,+: p<0.1, *: p<0.05, * *: p<0.01, * * *: p<0.001$

(a) F-test on two variance inequality of duration.

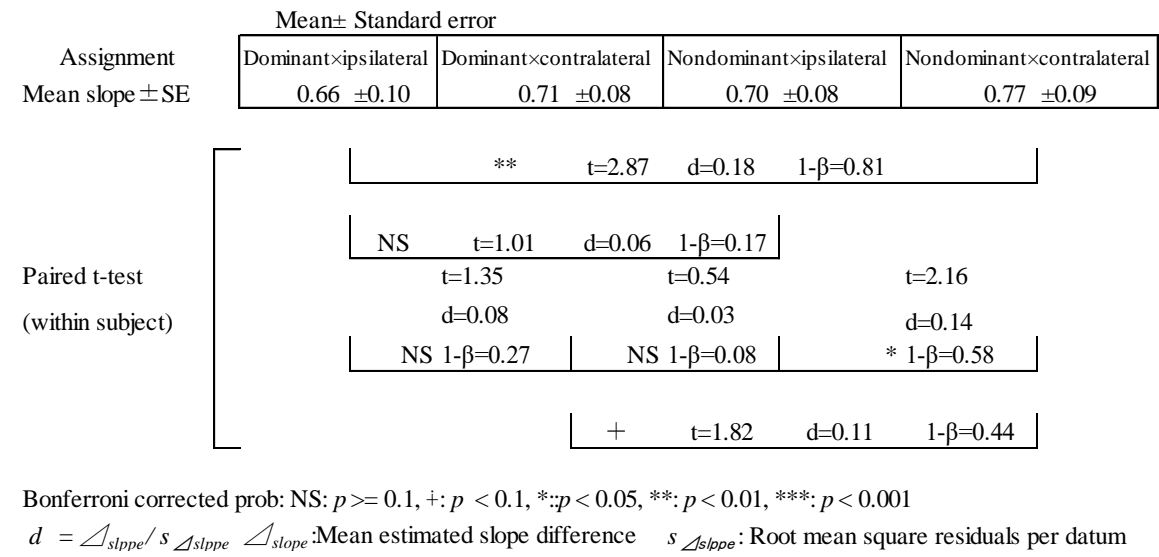

(b) Paired t-test for the population mean slope-differences.

Fig.7 Test results on time-duration perception-and-reproduction. 


\section{$3 \cdot 2$ 角度知覚}

提示角度に対する再現角度の誤差を図 8(a)に示す. 図 8(a)において，丸印は割当における再現角度の誤差の平 均を, エラーバーは標準偏差を表す. 図から, 再現角度の系統誤差, すなわち平均はいずれの割当でも大差なく, しかも偶然誤差，すなわちばらつきの標準偏差の 10 分の 1 程度と格段に小さかったため考えない.

次に，角度の残差の分散比の検定結果を図 8(b)に示す. 図のように分散は，利手-同側が $984.4 \mathrm{deg}^{2}$, 利手-反対 側が $1349.8 \mathrm{deg}^{2}$ ，非利手-同側が $749.9 \mathrm{deg}^{2}$ ，非利手-反対側が $883.0 \mathrm{deg}^{2}$ であった。総じて，分散は，知覚におい て非利手が利手より，再現において同側が反対側より優れる「非利手知覚-同側再現」優位傾向が見られる．分散 比の $F$ 検定結果において, 利手-反対側が他の三つの割当に対して有意に大きく, 劣っていると認められ, そのと きの効果量としての分散比はいずれも 1.4 以上であり基準值を概ね満たし, 検定力も基準值を概ね満たしていた.

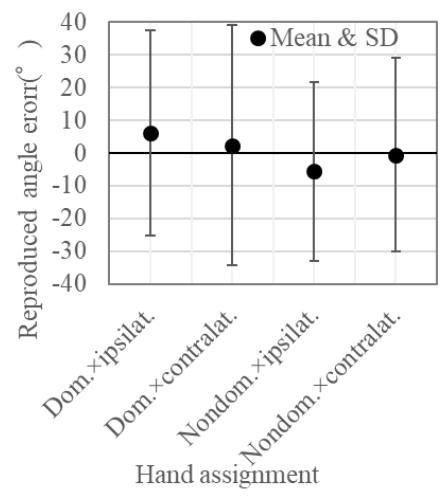

\begin{tabular}{|c|c|c|c|c|c|c|}
\hline \multirow[t]{5}{*}{$\begin{array}{l}\text { Assignment } \\
\text { Variance }\end{array}$} & \begin{tabular}{|c|} 
Dominant $\times$ ipsilateral \\
$984.4 \mathrm{deg}^{\wedge} 2$ \\
\end{tabular} & \multicolumn{2}{|c|}{\begin{tabular}{|c|} 
Dominant $\times$ contralateral \\
$1349.8 \mathrm{deg}^{\wedge} 2$ \\
\end{tabular}} & \multicolumn{2}{|c|}{$\begin{array}{c}\text { Nondominant } \times \text { ipsilateral } \\
749.9 \mathrm{deg}^{\wedge} 2 \\
\end{array}$} & $\begin{array}{c}\text { Nondominant } \times \text { contralateral } \\
883.0 \mathrm{deg}^{\wedge} 2\end{array}$ \\
\hline & & NS & $\mathrm{F}=1.1$, & $1-\beta=$ & 0.05560013 & \\
\hline & + & $\mathrm{F}=1.3$, & $1-\beta=$ & 0.3857644 & & \\
\hline & $\begin{array}{l}F=0.7, \\
1-\beta=\end{array}$ & * 0.5723163 & $\begin{array}{l}\mathrm{F}=1.8, \\
1-\beta=\end{array}$ & $\begin{array}{l}* * * \\
0.9869243\end{array}$ & $\begin{array}{l}\mathrm{F}=0.8, \\
1-\beta=\end{array}$ & $\begin{array}{l}\text { NS } \\
\quad 0.151142982\end{array}$ \\
\hline & & & & $\mathrm{F}=1.5$, & $1-\beta=$ & 0.822136504 \\
\hline
\end{tabular}

(a) Mean and standard deviation of reproduced angle error. (b) $F$-test of two variance inequality between all the pairs of assignments.

Fig. 8 Test results on angle perception-and-reproduction.

\section{$3 \cdot 3$ 総括的な評価}

運動の教示では，速さ，時間，角度，すべてが対象となることがある．さらに，さまざまな用途の中で静的な 情報としてのストロークの軌跡も重要な場合がある。この軌跡を表す代表的な特徴量としては「角度」の他にス トロークの始・終点間で定義される「長さ」が考えられる．この長さは速さと時間により与えられる．これらを ふまえ，本節では速さ，時間，角度の総合的な評価を試みる．利用目的に応じて各評価量の価值が異なることか ら，単純に有意差の有無を累積すればよいというものでもないが，一つの試みとして，上記の $3 \cdot 1,3 \cdot 2$ 節にお いて，知覚・再現した速さ，時間，そして角度の系統誤差および偶然誤差のそれぞれについて，4つの割当間で 定められる 6 対の対比較に関する有意差検定の結果を加算的にまとめた. すなわち，各評価量の価值が等しいと して，各対に関して得られた有意性の有無に基づいてポイントを定め，累積することで総合評価值とした。ポイ ントは， 0.05 以下 $(*, * *, * * *) の$ 有意水準で対間に差が認められた場合，優れていた割当に+ 1 , 劣っていた割当 にー 1 とした（対間で有意差が認められなかった場合には，両割当に 0 を付与). その結果を表 4 に示す. この表 から，総合的には，知覚・再現性能の序列として，「非利手-同側」=「非利手-反対側」>「利手-同側」>「利手反対側」が得られた。 今後, 本インタフェースを線画や曲線等の運筆学習に応用する場合, 利手を用いて運筆を 行うことから, 非利手で滑りを知覚し, 反対側の利手でストローク再現するような割当が良いと結論づけられる.

Table 4 Comprehensive comparison between the four perception×reproduction assignments: slopes represent systematic errors.

\begin{tabular}{c|c|c|c|c|c}
\hline \hline Reproduced value & Assignment & $\begin{array}{c}\text { Dominant } \times \\
\text { ipsilateral }\end{array}$ & $\begin{array}{c}\text { Dominant } \times \\
\text { contralateral }\end{array}$ & $\begin{array}{c}\text { Nondominant } \times \\
\text { ipsilateral }\end{array}$ & $\begin{array}{c}\text { Nondominant } \times \\
\text { contralateral }\end{array}$ \\
\hline Speed & Slope & -3 & 1 & 1 & 1 \\
\hline Time & Random error & -1 & -1 & 2 & 0 \\
\hline duration & Slope & -1 & 0 & -1 & 2 \\
\hline Direction & Random error & 1 & -2 & 1 & 0 \\
\hline Total & & 1 & -3 & 1 & 4 \\
\hline \hline
\end{tabular}




\section{$3 \cdot 4$ 従来研究との比較}

静的な知覚・再現特性としては, Goble et al. (2005) および Goble and Brown $(2008,2010)$ が，マニピュレータで 受動的に動かされた肘関節の屈曲角度を知覚し，同側／反対側の肘関節で再現する実験を行い，肘関節の屈曲角 度の誤差を評価した（図 9(a)参照)。これに対して，図 9(b)に本論文における静的物理量である再現角度の絶対誤 差（=誤差の 2 乗和の平方根）を示す. 図(a)と(b)を比較すると, 知覚対象が異なることから誤差の大きさも異な っているが，知覚・再現の割当に対応した誤差の大小のパターンはよく類似している．なお，図 9(a),(b), 図 10(a) では軸の值を反転させることで, 縦軸の最上部が理想值となるようにした. 次に, 動的な知覚・再現特性として, Goble and Brown (2009)は肘関節の屈曲角加速度の誤差を評価した（図 10(a)参照)。これに対して，図 10(b)に本論 文における動的物理量である再現速度の勾配を示す. 図 10(a)と(b)を比較すると, 少なくとも非利手を用いる割当 の方が利手を用いる割当より優れている点で共通している. 他方，再現に用いた腕に関しては，図 10(a)(b)間で， 本研究において非利手-反対側が非利手-同側と同程度に優れていることを除けば，それ以外の三つの割当間の優 劣に整合性が認められた.

静的な知覚量と考えられる角度において，本研究では，2 番手の非利手-反対側，すなわち非利手知覚-利手再現 との間に有意差はなかったものの, 非利手-同側, すなわち知覚・再現ともに非利手であることが他より優れてい た. これについては，時々刻々，指や腕を静止して得られるという意味で静的といえる滑りの知覚に関しては非 利手が優れていたと解釈できる. 他方, 動的な知覚量である速さにおいて，本研究では，非利手-同側，すなわち 非利手知覚-非利手再現と同程度であったが，非利手-反対側（非利手知覚-利手再現）は優れていた。これについ てはストローク再現で必要な手先の運動制御の点で利手が優れていたと解釈できる。このような静的および動的 な知覚・再現特性に関連しては, Sainburg (2002)が「非利手は静的な状態で自己受容感覚から伝えられる求心性の 信号に基づいて状態を認知し，その保持に努めるのに優れている. その一方，利手は運動制御に優れている」と の dynamic dominance hypothesis を提案している. その後, 困 9(c)の Goble and Brown (2009), Han et al. (2013)など もその仮説を再確認している. 本研究の結果もこの仮説に基づいて解釈でき，興味深い.

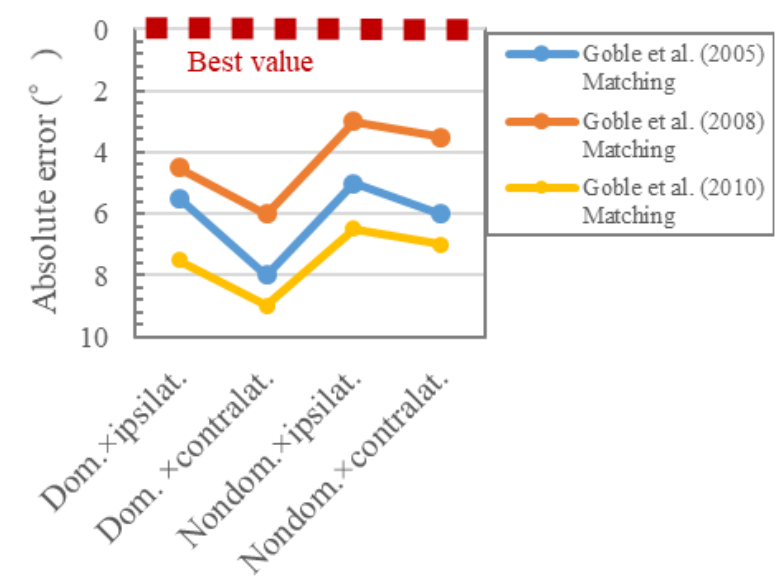

(a) Goble et al. $(2005,2008,2010)$ on angle

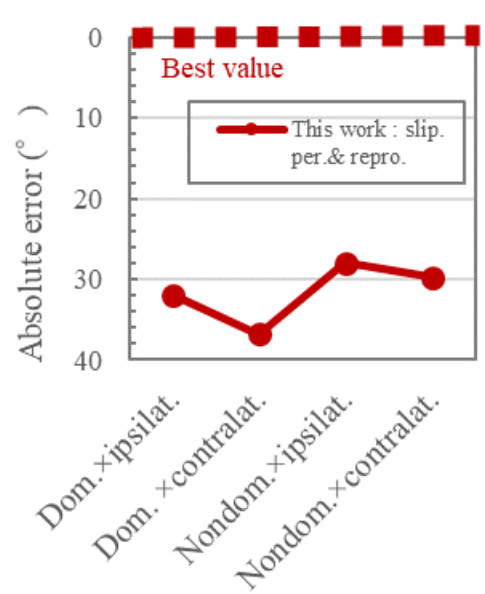

(b) This work on angle

Fig.9 Comparison of this work to some existing works with respect to a static feature. 


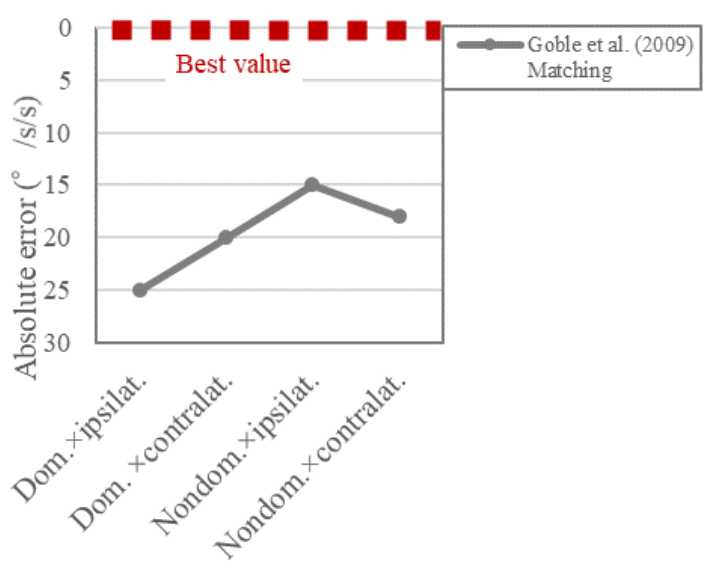

(a) Goble and Brown (2009) on acceleration.

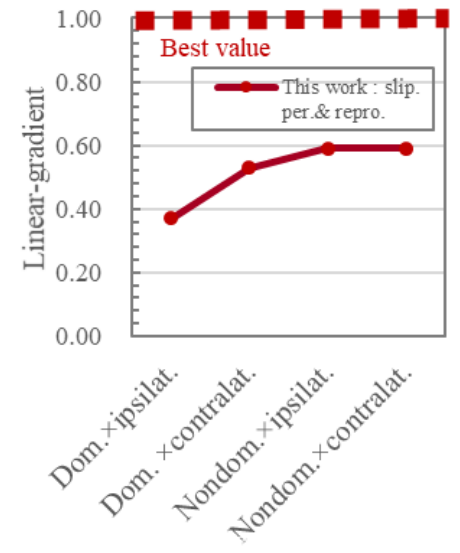

(b) This work on velocity.

Fig.10 Comparison of this work to an existing work with respect to dynamic features.

\section{4. 結言}

本研究では, 任意の方向, 速さ, 時間の滑りを指先の指腹部に提示できる装置として, 水平な中心軸の周りで 回転する小ホイール (直径 $20 \mathrm{~mm}$ ) の回転の角度と角速度, そして鉛直な軸周りでのホイール中心軸の旋回の角度 を制御できるアクティブホイール式指触覚インタフェースを用いた．その装置による滑りの提示特性を高めるた め, 知覚する手, および再現する手における利手, 非利手の優位性を調べた. まず, 知覚する手の因子として「利 手/非利手」の 2 水準, および再現する手の因子として知覚した手に対して「同側／反対側」の 2 水準を設定し, さらにこれらを組み合わせて $4 つ の$ 割当, すなわち利手-同側割当, 利手-反対側割当, 非利手-同側割当, 非利手反対側割当を設定した．次に，4つの割当により与えられる6つの割当対のそれぞれについて，速さ，時間，角 度の知覚・再現の偶然誤差の比を $F$ 検定で, 速さ, 時間の系統誤差の差を $t$ 検定で比較した. 得られた結果は以 下のようにまとめられる.

（1）速さ，時間，角度の個別評価は以下の通りである.

(i) 速さにおいては，偶然誤差および系統誤差のいずれにおいても，知覚因子では非利手が利手より有意に 優れる一方で，非利手知覚条件下での再現因子では反対側と同側の間に有意差は認められなかった.

(ii) 時間においては, 偶然誤差では利手-反対側のみが有意に劣り, 系統誤差では非利手-反対側のみが有意に 優れていた.

(iii) 角度においては，系統誤差は偶然誤差の $1 / 10$ 程度で非常に小さかった．偶然誤差では非利手知覚が有意 に優れる一方で，非利手知覚条件下での再現因子では反対側と同側の間に有意差は認められなかった。

（2）速さ，時間，角度の検定結果を積み重ねて総括的に評価した結果，非利手-同側と非利手-反対側が優れてい た.

(3) 角度, すなわち指や腕を静止して得られる静的な知覚量において, 非利手-同側, すなわち知覚，再現ともに 非利手が優れていた，他方，速さにおいては，非利手知覚-利手再現による非利手-反対側が，非利手-同側と 同程度に優れていた。これらから，手先が動かない条件下での静的物理量に関しては知覚・再現の両面で非 利手が優れ, 手先の運動制御に係る動的物理量に関しては非利手知覚・利手再現が優れていると解釈できる.

今後は，本実験の結果をふまえ，知覚・再現に用いる手として「非利手-反対側」割当を用い，滑りに関する变 位ベクトルと速度ベクトルを加味することで文字や図形などを描く運筆の学習への応用，効果的な学習方法の開 発などを行っていく予定である.

\section{謝辞}

本研究を進めるにあたり，三重大学総合情報処理センター杉浦徳広准教授には貴重な意見をいただいた．深く 感謝する. 本研究は, 科費費（15H02929）の助成による. 


\section{References}

Brockett, C., Warren, N., Gregory, J. E., Morgan, D. L. and Proske, U., A comparison of the effects of concentric versus eccentric exercise on force and position sense at the human elbow joint, Brain Research, Vol.771, No.2 (1997), pp. 251-258.

Buchner, A., Erdfelder, E., Faul, F. and Lang, A. G., G*Power 3.1 manual (2014), available from $<$ http://www.gpower.hhu.de/>, (accessed on 24 January, 2019) p. 41.

Cohen, J., Statistical power analysis for the behavioral sciences (2nd ed.), Hillsdale, NJ: Lawrence Erlbaum (1988).

Cohen, J., A power primer, Psychological Bulletin, Vol.112, No.1 (1992), pp. 155-159.

Djupsjöbacka, M. and Domkin, D., Correlation analysis of proprioceptive acuity in ipsilateral position-matching and velocity-discrimination, Somatosensory \& Motor Research, Vol.22, No.1-2 (2005), pp. 85-93.

Fraser, L. E. and Harris, L. R., The effect of hand position on perceived finger orientation in left-and right-handers, Experimental Brain Research, Vol.235, No.12 (2017), pp. 3683-3693.

Goble, D. J. and Brown, S. H., Upper limb asymmetries in the matching of proprioceptive versus visual targets, Journal of Neurophysiology, Vol.99, No.6 (2008), pp. 3063-3074.

Goble, D. J. and Brown, S. H., Dynamic proprioceptive target matching behavior in the upper limb: effects of speed, task difficulty and arm/hemisphere asymmetries, Behavioural Brain Research, Vol.200, No.1 (2009), pp. 7-14.

Goble, D. J. and Brown, S. H., Upper limb asymmetries in the perception of proprioceptively determined dynamic position sense, Journal of Experimental Psychology: Human Perception and Performance, Vol.36, No.3 (2010), pp. 768-775.

Goble, D. J., Lewis, C. A., Hurvitz, E. A. and Brown, S. H., Development of upper limb proprioceptive accuracy in children and adolescents, Human Movement Science, Vol.24, No.2 (2005), pp. 155-170.

Han, J., Waddington, G., Adams, R. and Anson, J., Bimanual proprioceptive performance differs for right-and left-handed individuals, Neuroscience Letters, Vol.542 (2013), pp. 37-41.

Ho, C., Kim, J., Patil, S. and Goldberg, K., The slip-pad: a haptic display using interleaved belts to simulate lateral and rotational slip, IEEE World Haptics Conference (WHC) (2015), pp. 189-195.

Koslover, R. L., Gleeson, B. T., De Bever, J. T. and Provancher, W. R., Mobile navigation using haptic, audio, and visual direction cues with a handheld test platform, IEEE Transactions on Haptics, Vol.5, No.1 (2012), pp. 33-38.

Lüttgen, J. and Heuer, H., Robotic guidance benefits the learning of dynamic, but not of spatial movement characteristics, Experimental Brain Research, Vol.222, No.1-2 (2012), pp. 1-9.

Nomura, Y. and Iwabu, K., Length perceptual characteristics on raised-dot slippages, Human-Computer Interfaces and Interactivity: Emergent Research and Applications, IGI Global (2014), pp. 286-308.

Nomura, Y., Kashino, Y. and Sugiura, T., Line-drawing presentation strategies with an active-wheel mouse, ACHI 2018: The Eleventh International Conference on Advances in Computer-Human Interactions (2018), pp. 199-203.

Nomura, Y. and Kato, H., Raised-dot slippage perception on fingerpad using active wheel device, Recent Advances on Using Virtual Reality Technologies for Rehabilitation, Nova Science Publishers, Inc. New York (2015), pp. 165-172.

Nomura, Y. and Oike, S., Active-wheel mouse for human-computer interface: slippage-perception characteristics on fingerpad, 10th International Conference, UAHCI 2016, Part II Part of HCI International (2016), pp. 54-61.

Provancher, W. R. and Sylvester, N. D., Fingerpad skin stretch increases the perception of virtual friction, IEEE Transactions on Haptics, Vol.2, No.4 (2009), pp. 212-223.

Sainburg, R. L., Evidence for a dynamic-dominance hypothesis of handedness, Experimental Brain Research, Vol.142, No. 2 (2002), pp. 241-258.

Tsay, A., Allen, T. J. and Proske, U., Position sense at the human elbow joint measured by arm matching or pointing, Experimental Brain Research, Vol.234, No.10 (2016), pp. 2787-2798.

Webster III, R. J., Murphy, T.E., Verner, L. N. and Okamura, A. M., A novel two-dimensional tactile slip display: design, kinematics and perceptual experiments, ACM Transactions on Applied Perception (TAP), Vol. 2, No. 2 (2005) pp. $150-165$. 